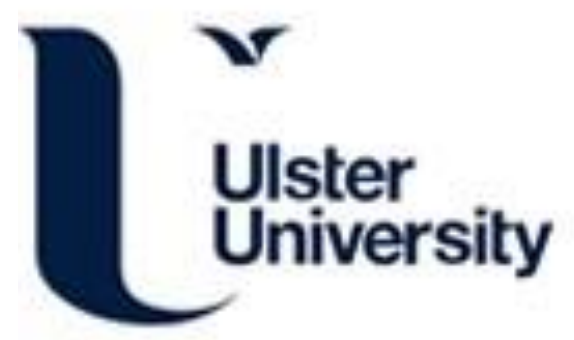

\title{
Investigation of the processing characteristics and mechanical properties of metallocene-catalysed polyethylene foams for rotational moulding
}

Archer, E., Harkin-Jones, E., Kearns, MP., \& Fatnes, AM. (2003). Investigation of the processing characteristics and mechanical properties of metallocene-catalysed polyethylene foams for rotational moulding. Journal of Cellular Plastics, 39(6), 487-497. https://doi.org/10.1177/002195503039213

Link to publication record in Ulster University Research Portal

Published in:

Journal of Cellular Plastics

Publication Status:

Published (in print/issue): 01/11/2003

DOI:

$10.1177 / 002195503039213$

Document Version

Publisher's PDF, also known as Version of record

\section{General rights}

Copyright for the publications made accessible via Ulster University's Research Portal is retained by the author(s) and / or other copyright owners and it is a condition of accessing these publications that users recognise and abide by the legal requirements associated with these rights.

\section{Take down policy}

The Research Portal is Ulster University's institutional repository that provides access to Ulster's research outputs. Every effort has been made to ensure that content in the Research Portal does not infringe any person's rights, or applicable UK laws. If you discover content in the Research Portal that you believe breaches copyright or violates any law, please contact pure-support@ulster.ac.uk. 


\section{Journal of Cellular Plastics}

http://cel.sagepub.com

\section{Investigation of the Processing Characteristics and Mechanical Properties of Metallocenecatalysed Polyethylene Foams for Rotational Moulding \\ E. Archer, E. Harkin-Jonesy, M. P. Kearns and A. M. Fatnes Journal of Cellular Plastics 2003; 39; 487 \\ DOI: $10.1177 / 0021955 \times 03039213$}

The online version of this article can be found at: http://cel.sagepub.com/cgi/content/abstract/39/6/487

Published by:

(3)SAGE

http://www.sagepublications.com

Additional services and information for Journal of Cellular Plastics can be found at:

Email Alerts: http://cel.sagepub.com/cgi/alerts

Subscriptions: http://cel.sagepub.com/subscriptions

Reprints: http://www.sagepub.com/journalsReprints.nav

Permissions: http://www.sagepub.co.uk/journalsPermissions.nav

Citations http://cel.sagepub.com/cgi/content/refs/39/6/487 


\title{
Investigation of the Processing Characteristics and Mechanical Properties of Metallocene- catalysed Polyethylene Foams for Rotational Moulding*
}

\author{
E. ARCHER, E. HARKIN-JONES ${ }^{\dagger}$ AND M. P. KEARNS \\ Polymer Processing Research Centre \\ The Queens University of Belfast \\ Northern Ireland
}

A. M. FATNES

Borealis AS, N-3960 Stathelle, Norway

\begin{abstract}
The object of this work is to investigate the foaming characteristics of three grades of metallocene-catalysed linear low-density polyethylenes for rotational moulding using both an exothermic and endothermic chemical blowing agent. This paper reports on the results of ongoing experimental investigations in which rheological and thermal parameters are related to the polymer structure and mechanical properties. Through adjustments to moulding conditions, the significant processing and physical material parameters, which optimise metallocene-catalysed linear low-density polyethylene foam structure, have been identified. The results obtained from equivalent conventional grades of Ziegler-Natta-catalysed linear low-density polyethylene are used as a basis for comparison.
\end{abstract}

KEY WORDS: rotational moulding, polyethylene, foam, metallocene.

\footnotetext{
*This revised paper was presented in its original form at the Annual Technical Conference 2003 (ANTEC '03), May 4-8, Nashville, Tennesse, and copyright is held by the Society of Plastics Engineers.

${ }^{\dagger}$ Author to whom correspondence should be addressed.
} 


\section{INTRODUCTION}

This project aims to investigate the foaming process in a new range 1 of materials that have been previously found to improve unfoamed processing and mechanical properties [1]. These materials are known as metallocene polyethylene (MPE) because of the metallocene catalyst used during polymerisation [2]. It is because of their narrower molecular weight distribution that metallocene polyethylenes were thought to be well-suited for use in rotational moulding. This work will investigate their suitability for producing foam during rotational moulding by comparing a wide range of properties (mechanical, processing, rheological, thermal and polymeric structure) of foamed metallocene polyethylene to foamed conventional (Ziegler-Natta) polyethylene.

Although there are numerous ways to produce foamed polymeric materials [3], blowing agents (BA) or foaming agents are thought to be the most practical for use in rotational moulding to produce foam in foamed plastics.

Foam is a disperse system of gas and solid polymer matrix [4]. There are two basic means of creating the gas phase in the matrix. It can be injected into the polymer mix known as physical foaming, or it can be developed by the chemical decomposition of a solid powder in the melt, known as chemical foaming.

For several reasons, it has been realised that physical blowing agents are not well-suited for use in rotational moulding, so chemical blowing agents have been used in several ways to produce skinned foam. As the final foam structure depends largely on the properties of the blowing agent, great care must be taken when choosing a blowing agent. Using a blowing agent compatible with polymer can offer a unique economic or performance advantage. As metallocene polyethylene differs from conventional polyethylene, work was initially undertaken to find a suitable blowing agent.

The objective is to determine whether or not metallocene polyethylene can deliver the same advantages to foamed rotational moulding as it has done with unfoamed rotational moulding through:

- Identification of efficient and versatile blowing agent for rotomoulded foams.

- Identification of polymer structure influencing the foamability of the polymer.

- Identification of the significant processing and physical material parameters in rotational moulding of foamed metallocene polyethylenes.

- Correlation of foamed structure with mechanical performance. 


\section{EXPERIMENTAL}

The following experimental work was conducted:

- Materials and blowing agent characterisation.

- Moulding of various materials and blowing agent combinations.

- Measurement of moulded part properties and structure.

\section{Materials}

Three commercial grades of metallocene catalysed LLDPE powder and one grade of Ziegler-Natta catalysed LLDPE powder were sourced for comparison for their foaming ability in rotational moulding (Table 1). Each material is identified with a code indicating the type of catalyst used (ZN for Ziegler-Natta, M for Metallocene), followed by the melt flow index, and finally the density, e.g. M/6/940 is a metallocene grade with a MFI of $6 \mathrm{~g} / 10 \mathrm{~min}$ and a density of $940 \mathrm{~kg} / \mathrm{m}^{3}$.

\section{Blowing Agent}

An endothermic and exothermic blowing agent (BA) that had been found to perform well in previous work [5] were chosen (see Table 2). A Perkin-Elmer TGS 2 was used to measure the change in the mass

Table 1. Details of polymers used.

\begin{tabular}{lcccc}
\hline Material & $\begin{array}{c}\text { Supplier } \\
\text { Code }\end{array}$ & Type & $\begin{array}{c}\text { MFR } \\
(\mathrm{g} / 10 \mathrm{~min})\end{array}$ & $\begin{array}{r}\text { Density } \\
\left(\mathrm{kg} / \mathrm{m}^{3}\right)\end{array}$ \\
\hline M/6/934 & RMB343 & MPE & 6 & 934 \\
$M / 4 / 940$ & RM7403 & MPE & 4 & 940 \\
$M / 6 / 940$ & RMB403 & MPE & 6 & 940 \\
ZN/3.6/934 & MEB152 & LLDPE & 3.6 & 934 \\
\hline
\end{tabular}

Table 2. Details of blowing agents used.

\begin{tabular}{lcccc}
\hline Type & Grade Name & $\begin{array}{c}\text { Decomposition } \\
\text { Temperature }\left({ }^{\circ} \mathrm{C}\right)\end{array}$ & Gas Yield $(\mathrm{mL} / \mathrm{g})$ & Gas Type \\
\hline Exothermic & Celogen OT & 158 & 125 & $\mathrm{~N}_{2} / \mathrm{H}_{2} \mathrm{O}$ \\
Endothermic & Hydrocerol BIH & 140 & 210 & $\mathrm{CO}_{2}$ \\
\hline
\end{tabular}


of a sample over a temperature range. In thermogravimetric analysis, sample weight can be plotted as a function of time for isothermal studies or as a function of temperature for experiments at constant heating rate, as is the case of this study. A sample of blowing agent (approximately $1 \mathrm{mg}$ ) was placed in a platinum pan and heated at $10^{\circ} \mathrm{C} / \mathrm{min}$ to $250^{\circ} \mathrm{C}$ under a steady flow of nitrogen. It was found that the endothermic blowing agent had a decomposition temperature of $140^{\circ} \mathrm{C}$, and the exothermic blowing agent had a decomposition temperature of $158^{\circ} \mathrm{C}$. From supplier data, it is known that the exothermic blowing agent has an average particle size of approximately $6 \mu$, and the endothermic blowing agent has an average particle size of approximately $11 \mu$.

\section{Rotational Moulding}

As it is very important to have the blowing agent thoroughly dispersed in the polymer powder prior to charging the mould, $20 \mathrm{~kg}$ of each PE/BA mix was blended in a Caccia AVO 150C Turbo blender running at $1400 \mathrm{rpm}$ and at a temperature of $60^{\circ} \mathrm{C}$. In this paper, a polymer name followed by 'ENDO' means than the polymer was blended with the endothermic blowing agent and vice versa, e.g. M/6/ 940 EXO denotes metallocene grade with a MFI of $6 \mathrm{~g} / 10 \mathrm{~min}$ and a density of $940 \mathrm{~kg} / \mathrm{m}^{3}$ blended with the exothermic BA. The PE/BA mix was calculated so that each batch would produce the same volume of evolved gas after the BA decomposition temperature had been reached (The volume of gas evolved per gram of BA was specified by each of the manufacturers and corroborated by TGA analysis). The endothermic blowing agent was blended to $0.9 \%$ by weight, and the exothermic blowing agent, as it has a lower evolved gas volume per mass, was blended to $1.52 \%$ by weight. With this formulation, the volume of gas evolved for each $\mathrm{kg}$ of $\mathrm{PE} / \mathrm{BA}$ mix was $1.9 \mathrm{~L}$.

The mould trials were carried out over a range of temperatures using both the endothermic and exothermic blowing agent. The mould was removed from the oven into the cooling area once internal mould air temperatures of 135,155 and $175^{\circ} \mathrm{C}$ were achieved, as previous work had shown that oxidation would begin to occur at higher temperatures.

Each blend was rotationally moulded using a Caccia AR 1400 shuttle type rotational moulding machine with an oven temperature of $300^{\circ} \mathrm{C}$. Mouldings were produced in a $300 \mathrm{~mm}$ steel cube mould. A shot weight 
of $1.9 \mathrm{~kg}$ was used in each trial. This size of shot was known to produce a $3 \mathrm{~mm}$ unfoamed moulding.

A further trial was conducted using 3 and $5 \%$ exothermic BA addition (by weight) on $\mathrm{M} / 4 / 940$ and $3 \%$ on the other materials.

\section{Density}

Density measurement was performed using a Mettler Toledo PG-S balance equipped with a density determination kit.

A $15 \mathrm{~mm} \times 15 \mathrm{~mm} \mathrm{PE}$ foam sample was cut from the mould wall to make a cube with depth equal to the wall thickness of the moulding. This sample was first weighed in air and then immersed in distilled water to measure the sample buoyancy. As the foamed PE was less dense than water, a Titanium wire cage was used to keep the sample submerged, hence allowing the buoyancy to be measured.

\section{Cell Content}

A cross section of each of the first set of mouldings was cut and mounted on aluminium microscope slides. An Agar Auto Sputter coater was used for sputtering a conductive gold layer onto the scanning electron microscope samples to prevent charging effects. A micrograph of each sample was then taken using the JEOL 6400 Scanning Electron Microscope.

Image-Pro Plus software was used to perform a bubble size analysis. The process involved setting up a spatial calibration for the magnification used by the microscope, converting the images to black and white, applying flattening and spectral filters and masks, creating an area of interest containing only foam. The final step involved counting and measuring the foam bubbles to obtain an average value. The value given is the average cross-sectional area of the cells.

\section{Flexural Test}

Three-point flexural tests were performed on a JJ Lloyd M30K computer-controlled machine according to ASTM D790 [6]. The support span was 16 times the depth of the sample. Depending on the nominal specimen depth, the rate of crosshead motion was varied according to the standard. The tests were repeated five times, and an average value of the $2 \%$ secant modulus was taken. The tests were performed with the outside face of the moulding being in contact with the crosshead to represent service conditions of the moulded part. 


\section{RESULTS AND DISCUSSION}

\section{Density}

Figure 1 shows the foam density of the materials as a function of internal mould air temperature at which the mould was removed from the oven (IAT).

The lowest foam density attained in the first set of mould trials is $0.266 \mathrm{~g} / \mathrm{cm}^{3}$ using the exothermic blowing agent which produces $91 \% \mathrm{~N}_{2}$. This low density is achieved using both M/6/934 and M/4/940, although $\mathrm{M} / 6 / 934$ did experience a slight increase in density at the highest processing temperature. It was noted that $\mathrm{M} / 6 / 940$ and $\mathrm{ZN} / 3.6 / 934$ have a higher density of over $0.3 \mathrm{~g} / \mathrm{cm}^{3}$ at the lowest processing temperature. Both these densities fell, with M/6/940 experiencing a larger reduction in foam density as a higher IAT was used. M/6/940 fell to $0.27 \mathrm{~g} / \mathrm{cm}^{3}$ and $\mathrm{ZN} / 3.6 / 934$ fell to $0.29 \mathrm{~g} / \mathrm{cm}^{3}$. With this blowing agent, there is an $8 \%$ difference between the lowest and highest foam density recorded for the 4 grades irrespective of their different viscosity and melt strength.

On the other hand, there is a large spread in the density of foams produced using the endothermic blowing agent. The lowest foam density attained using the endothermic blowing agent, which produces $\mathrm{CO}_{2}$, is $0.37 \mathrm{~g} / \mathrm{cm}^{3}$, when used with $\mathrm{M} / 6 / 940 . \mathrm{M} / 4 / 940$ gives a foam with a much higher density of approximately $0.6 \mathrm{~g} / \mathrm{cm}^{3}$, giving a $38 \%$ difference between the lowest and highest density achieved. It was also noted that

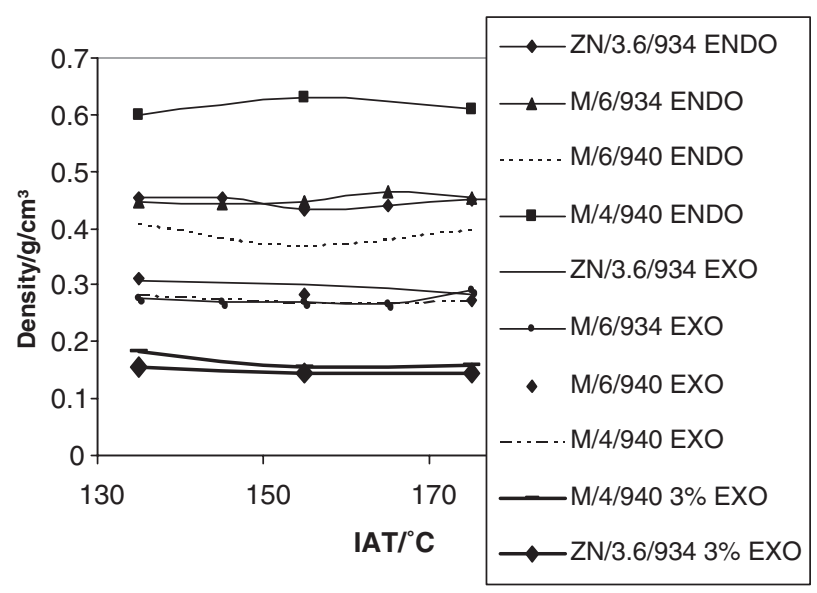

Figure 1. Relationship between foam density and IAT. 
$\mathrm{M} / 6 / 934$ and $\mathrm{ZN} / 3.6 / 934$ have a similar foam density to one another (approximately $0.45 \mathrm{~g} / \mathrm{cm}^{3}$ ).

There is a distinct difference between densities of foams produced using exothermic and endothermic blowing agents. Exothermic blowing agents produce foams with a low density (approximately $0.3 \mathrm{~g} / \mathrm{cm}^{3}$ ), and endothermic blowing agents produce foam with higher density (approximately $0.45 \mathrm{~g} / \mathrm{cm}^{3}$ ).

When processed with $5 \%$ BA addition, M/4/940 gives a poor foam structure with large voids. When processed with $3 \%$, the density reduction is large and the foam structure is free from voids. The lowest density in this case is $0.156 \mathrm{~g} / \mathrm{cm}^{3}$ (Figure 1, lines for $3 \% \mathrm{EXO}$ ). $\mathrm{ZN} / 3.6 / 934$ was also tested in the same way giving the lowest density of $0.145 \mathrm{~g} / \mathrm{cm}^{3}$.

At $3 \%$ BA addition, $\mathrm{M} / 6 / 940$ and $\mathrm{M} / 6 / 934$ gave a similar structure to $\mathrm{M} / 4 / 940$ at $5 \%$ with voids present, so further tests were not conducted with these combinations.

\section{Cell Size}

There are several similarities between the average bubble sizes obtained for both blowing agents (see Figures 3 and 4). In both cases $\mathrm{M} / 4 / 940$ has the smallest bubble size, followed by $\mathrm{M} / 6 / 934$ and $\mathrm{ZN} / 3.6 /$ 934 at similar size, and $\mathrm{M} / 6 / 940$ having the largest value. The endothermic BA gives a smaller minimum average bubble size of approximately $0.03 \mu \mathrm{m}^{2}$, whereas the exothermic blowing agent gives a minimum average bubble size of approximately $0.04 \mu \mathrm{m}^{2}$. Conversely,

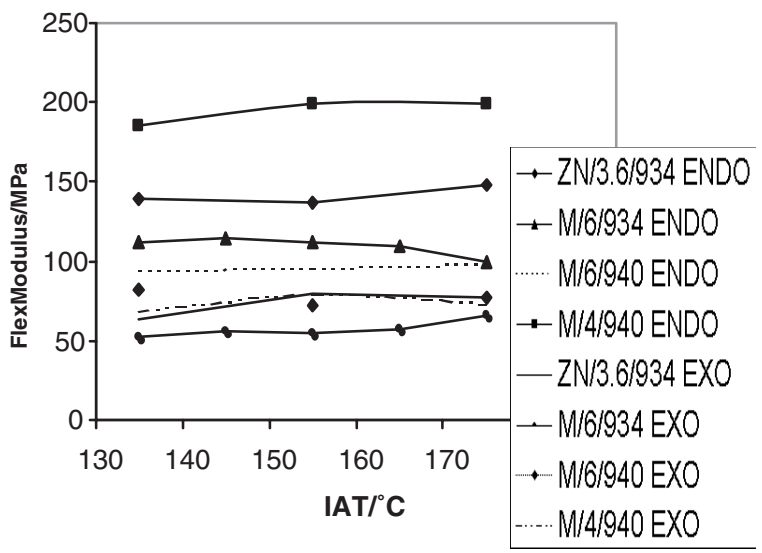

Figure 2. Relationship between flexural modulus and IAT. 


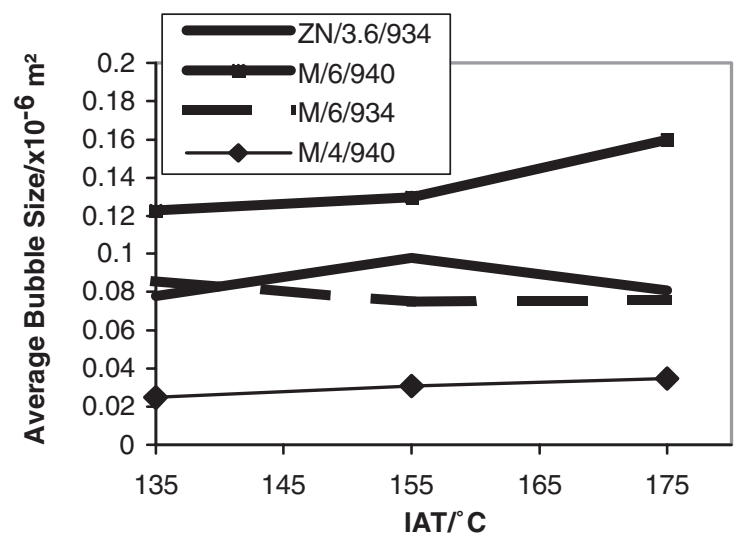

Figure 3. Relationship between cell size and IAT with endothermic blowing agent.

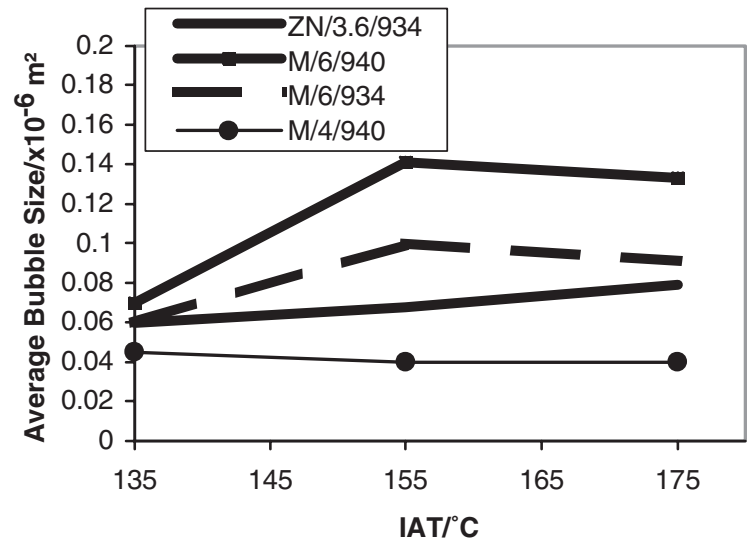

Figure 4. Relationship between cell size and IAT with exothermic blowing agent.

the endothermic blowing agent has a larger maximum bubble size with $\mathrm{M} / 6 / 940$ of approximately $0.16 \mu \mathrm{m}^{2}$ (at IAT of $175^{\circ} \mathrm{C}$ ), whereas the exothermic blowing agent gives a minimum average bubble size of approximately $0.14 \mu \mathrm{m}^{2}$ (at IAT of $155^{\circ} \mathrm{C}$ ).

There is a general upward trend between average bubble size and internal air temperature. It was also noted that $\mathrm{M} / 4 / 940$ is least sensitive to changes in processing temperature and M/6/940 the most sensitive. When comparing $\mathrm{ZN} / 3.6 / 934$ with $\mathrm{M} / 4 / 940$, it can be seen that, for a similar MFR, both blowing agents (Figures 3 and 4) show the metallocene, catalysed polyethylene foam has a smaller average bubble 
size than the Zeigler-Natta catalysed polyethylene. It is also noted, however, that the two materials with identical MFR values, M/6/940 and M/6/934, do not have a similar average bubble size, suggesting that MFR may not be the most important parameter in rotational moulding of foam.

\section{Flexural Test}

Figure 2 shows the flexural modulus of the materials as a function of IAT. When observing foams produced using both the endothermic and the exothermic blowing agents, it can be seen that the density does not vary with the oven removal temperature, and likewise the flexural modulus remains almost constant. The foams that were processed using the endothermic blowing agent have a higher density and therefore a larger flexural modulus than foams produced using the exothermic blowing agent.

When moulded with the endothermic BA, M/4/940 gives a flexural modulus result that was initially very surprising and if viewed alone without the density being measured relative to the other specimens, may appear unrealistic. The tests concluded that this foam has a flexural modulus of approximately $200 \mathrm{MPa}$, whereas the next highest material $(\mathrm{ZN} / 3.6 / 934)$, although processed in the same way with the same blowing agent, has a flexural modulus of $140 \mathrm{MPa}$, a reduction of $20 \%$. Although $\mathrm{ZN} / 3.6 / 934$ and $\mathrm{M} / 6 / 934$ have similar foam densities, $\mathrm{ZN} / 3.6 / 934$ does seem to have a slight advantage for flexural strength, as ZN/3.6/934 has a value of approximately $140 \mathrm{MPa}$, whereas M/6/934 has a value of approximately $110 \mathrm{MPa}$. M/6/940 has both the lowest density and flexural modulus of the 4 materials processed with the endothermic BA.

When moulded with the exothermic BA, it was found that the foam densities and mechanical properties had a smaller distribution between materials making it more difficult to pinpoint variations in flexural properties. It can be seen that $\mathrm{M} / 6 / 934$ has both a low density of approximately $0.27 \mathrm{~g} / \mathrm{cm}^{3}$ and low flexural modulus of approximately $55 \mathrm{MPa}$. When $\mathrm{M} / 4 / 940$ is processed with the exothermic BA, it has both a low foam density of approximately $0.27 \mathrm{~g} / \mathrm{cm}^{3}$ and high flex modulus of approximately $77 \mathrm{MPa}$. It was initially suspected that this may be attributed to the relatively high base resin flex modulus of $750 \mathrm{MPa}$, but it was also observed that $\mathrm{M} / 6 / 940$ has an equally high base resin flex strength but did not show a large foamed flex strength per unit density. When moulded with the exothermic BA, M/6/940 gives a large flex modulus at low IAT, but it was observed that, in keeping with the 
relationship between foam density and flexural modulus, the density was also marginally higher at the lower oven removal temperature. The most obvious conclusion is that the smaller average bubble size produced by $\mathrm{M} / 4 / 940$ may have given a marginal advantage to the foams flexural modulus for the nominal foam density.

Figure 5 shows the flexural properties of the materials processed with $3 \% \mathrm{BA}$ addition. $\mathrm{M} / 4 / 940$ gives a flex modulus of $23 \mathrm{MPa}$ at $135^{\circ} \mathrm{C}$, falling to $19 \mathrm{MPa}$ as the IAT rises, and $\mathrm{ZN} / 3.6 / 934$ gives a flex modulus of $16 \mathrm{MPa}$ increasing to $19 \mathrm{MPa}$ as the IAT reaches $175^{\circ} \mathrm{C}$.

There is a very strong linear correlation between flexural modulus and foam density for all material and blowing agent combinations tested (Figure 6). As the density of the foam falls, the flexural modulus also

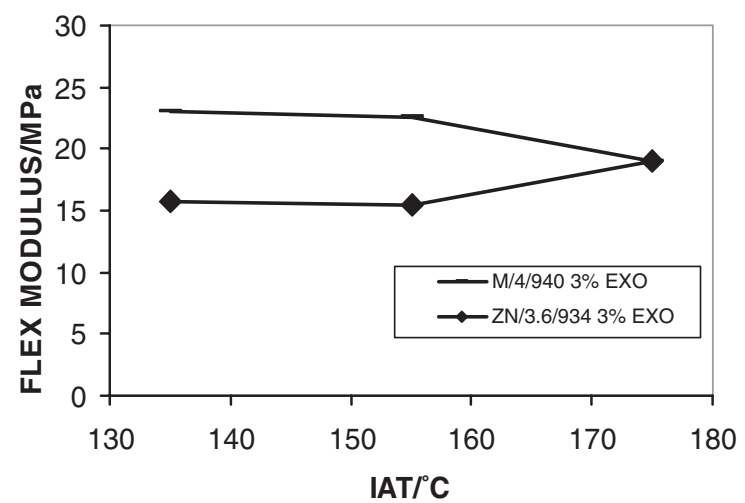

Figure 5. Relationship between flexural modulus and IAT with $3 \%$ BA addition.

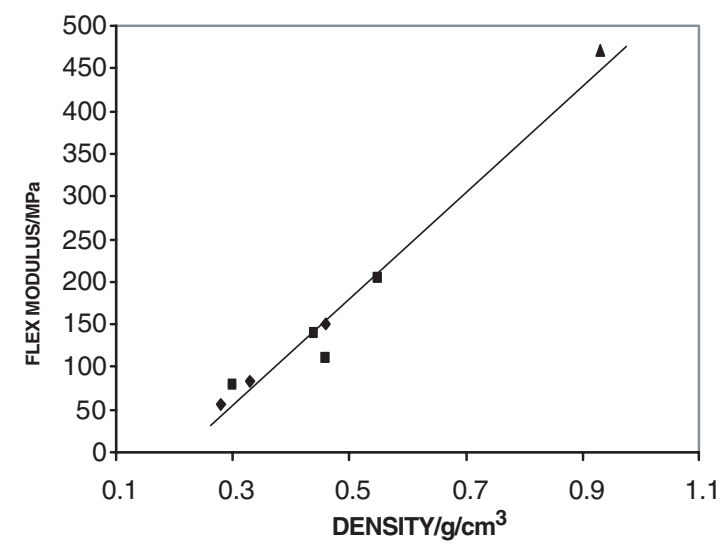

Figure 6. Relationship between foam density and flexural modulus. 
falls, regardless of material or blowing agent type. This relationship can be used to determine the density required to produce a foamed part with a given stiffness.

\section{CONCLUSIONS}

- By using the correct processing conditions (lower oven removal temperature), metallocene-catalysed LLDPE can be used in rotational foam moulding to produce a foam that will perform as well as a Ziegler-Natta catalysed foam.

- Foam density is by far the most influential parameter over flexural properties of foam.

- There is a positive linear relationship between both flexural modulus and compressive strength with foam density.

- The average cell size generally increases as the oven removal temperature increases for both Zeigler-Natta and metallocenecatalysed polyethylene.

- Under the experimental procedures, the exothermic blowing agent (releasing nitrogen) produces foams with a lower density than the endothermic blowing agent (releasing carbon dioxide).

- For a given MFR, the results indicate that the cell size in metallocene-catalysed foam will be smaller and less sensitive to change in the temperature of mould removal from the oven than a Ziegler-Natta catalysed foam.

- With the addition of 3\% exothermic blowing agent, the two materials with a MFR of 6 gave a foam structure with voids whereas the materials with a MFR of 4 and 3.6 did not.

\section{REFERENCES}

1. Wang, X. (2000). Rotational Moulding of Metallocene Grades of Polyethylene, QUB. PhD Thesis.

2. Peacock, A.J. (2000). Handbook of Polyethylene, Structures, Properties and Applications, Marcel Dekker, Inc. p. 40.

3. Klempner, D. and Frisch, K. (1992). Polymeric Foams, Hanser.

4. Scholz, D. (1998). How to Get the Most Out of Chemical Foaming Agents, Boehringer Ingelheim Pharma KG, Germany.

5. Archer, E., Harkin-Jones, E., Kearns, M. and Fatnes, A.M. (2002). SPE ANTEC Tech. Papers.

6. American Standard for Testing Materials - ASTM D790M-93, Standard Test Method for Flexural Properties of Unreinforced and Reinforced Plastics and Electrical Insulating Materials. 